\title{
The Implementation Strategy of Education in Higher Vocational Colleges
}

\author{
Chao LIU \\ Department of computer \\ Wuhan polytechnic \\ Wuhan 430074, China \\ 2093135999@qq.com
}

\begin{abstract}
This paper expounds the knowledge and ability of innovative and entrepreneurial teachers, and probes into the countermeasures for improvement and development of innovative and entrepreneurial education teaching ability of university teachers from the aspects of innovation and entrepreneurship education concept, evaluation and incentive, learning and training, teaching and research. Only building a high-level innovative and entrepreneurial teacher team is not only a prerequisite for improving the innovative and entrepreneurial ability of college students, but also can guarantee the teaching quality of innovative and entreprene urial education and train the successors with high socialist quality in the new era.
\end{abstract}

Keywords-Entrepreneurship education; University-enterprise cooperation; The ability to start a business; Job entrepreneurship; Dual teacher team structure.

\section{INTRODUCTION}

The innovation-driven development strategy being implemented in China is essentially to promote economic and social development with science and technology and talents. "It has become a common practice around the world to cultivate young people's entrepreneurial ability and entrepreneurial spirit by launching education to store human capital for economic development." The implementation opinions of the general office of the state council on deepening the reform of innovation and entrepreneurship in institutions of higher learning education (issued by the office of the state council [2015] no. 36) proposed to give full play to the important role of innovation and entrepreneurship education in implementing the national strategy of innovation-driven development. We will strive to make college students a new force for mass entrepreneurship and innovation. As an important part of institutions of higher learning, it is a new requirement for higher vocational colleges to cultivate innovative and entrepreneurial talents with technical skills to promote the further development of education. Because education and education in higher vocational colleges have different types and different realistic conditions, entrepreneurial education in higher vocational colleges should have unique value orientation, goal and implementation path.

\section{EDUCATION AIMS TO PROMOTE THE ALL-ROUND AND FREE DEVELOPMENT OF STUDENTS}

Value is always relative to a particular subject. The garden embodies a special relationship between subject and object. As the main body to implement education. Higher vocational colleges must have a specific value orientation in the process of starting business education, and this value orientation is closely related to the type characteristics of vocational education. According to UNESCO. Higher vocational education aims to "enhance personal ability and promote employment, decent work and lifelong learning" and "achieve personal aspirations". Our government also attaches great importance to making "everyone has a chance to make a difference in life" through education. The value orientation of education should be consistent with that of professional education, that is, students should realize their own value and promote their comprehensive and free development. Comprehensive and free development is not all-encompassing development, but full expression of individual self-worth, "promoting responsible citizenship and democratic participation in the development of knowledge, skills and capabilities." In the western education thought development process. Whether it is a "natural person" with the ability to harmonize developed mind and body and engage in productive labor. Or by working education to cultivate useful citizens. As well as the democratic education advocacy of "doing secondary school", both clearly expressed the professional education promotion of individuals to achieve self-realization, comprehensive and free development of the ideal. At present, students who accepted higher education at education were mostly labeled "underachievers" and received far more criticism than praise from their academic experience. However. From all levels of various skills competition and specific work practice. Compared with abstract thinking training. These students are more suitable for image thinking training. That is to say through the appropriate education. They can also achieve self-worth. In view of this, the promotion of vocational college students comprehensive and free development of entrepreneurship education. It is mainly reflected in three aspects: first, to stimulate students' innovative consciousness. Second: cultivate students' innovation ability. Third: help students to correctly understand innovation activities. 
III. THE DUAL GOAL OF EDUCATION IN HIGHER VOCATIONAL COLLEGES

\section{A. Cultivate students' ability to start a business}

The main task of education is to cultivate students' innovative consciousness and basic qualities of entrepreneurship. The highest goal of education is to cultivate students' ability to start enterprises and start their own enterprises. This is also the goal that education can achieve through efforts of higher vocational colleges. Education is closely related to economic and social development in higher vocational colleges. The professional setting of higher vocational colleges depends on regional pillar industries. All of these are for higher vocational colleges to train students to establish enterprises through entrepreneurship education. Under the background of mass entrepreneurship, they should not only give full play to the function of higher vocational education to "find jobs". More importantly, we should explore its function of "making rice bowl".

\section{B. Cultivate the ability of students to start their own businesses}

As a teaching activity to meet the needs of economic and social development, entrepreneurial education, in what ways to practice entrepreneurial education, has aroused people's deep thinking and various explorations. It has been proved by practice that school-enterprise cooperation is one of the important ways to launch education. This has been reflected in relevant national policies. Education teaching basic requirements (trial) issued by the ministry of education requires institutions of higher learning to carry out entrepreneurial activities through school-enterprise cooperation. Schoolenterprise cooperation is also the basic experience of the rapid development of education in China's higher vocational colleges. By carrying out education entrepreneurship through schoolenterprise cooperation, higher vocational colleges cultivate students' ability to establish enterprises and start businesses in posts, and have more practical advantages. In this study, education implementation strategies based on school-enterprise cooperation were constructed from four aspects: education content, education course system, innovation and entrepreneurship project incubation platform and education teaching team.

\section{EDUCATION IMPLEMENTATION STRATEGY BASED ON SCHOOL-ENTERPRISE COOPERATION}

To reflect the characteristics of vocational education content of entrepreneurship education is an important carrier of the implementation of entrepreneurship education, the education content in higher vocational colleges to introduce advanced foreign entrepreneurship education or university entrepreneurship education content of its own development of entrepreneurship education in colleges and universities are important reference, but the content of entrepreneurship education in higher vocational colleges need to reflect characteristics of vocational education more. With the deepening of theoretical research and practical exploration of entrepreneurial education in higher vocational colleges, the contents of entrepreneurial education should start from the types, levels, characteristics and actual conditions of the school At present, the entrepreneurial education content of higher vocational colleges does not have obvious vocational education characteristics. In terms of content selection, although it covers the conceptual knowledge of entrepreneurship and the basic knowledge of entrepreneurial ability, entrepreneurial consciousness, entrepreneurial spirit, entrepreneurial mode and entrepreneurial environment. However, the content of education is less intersecting with professional technical skills. Selected the entrepreneurial education teaching content in the case is far from real life and technical skills in higher vocational colleges students, neither is introduced in the history of Karl Benz use their own technical skills to create the world's first engine, founded the world-famous Mercedes-Benz enterprises: without telling as countries such as the Gao Fenglin artisans. Quietly adhere to the ordinary job, the pursuit of professional skills and perfection, with action interpretation of the post entrepreneurship. The entrepreneurial education content that reflects the characteristics of vocational education should not only achieve the entrepreneurial education goal, but also stimulate students' enthusiasm for learning professional knowledge and technical skills. Therefore, higher vocational colleges need to cooperate with enterprises and jointly screen the entrepreneurial education content, so as to present the process of technological innovation and development in vocational work to students, and explain the important role of new technical skills or new management methods in the process of enterprise development in combination with students' majors. Take technological innovation for example. Entrepreneurship education content to tell students focus on the new technology, new equipment and new organization and management way is how to improve the economic efficiency of enterprises, and guide students in the learning process, improve the required technical skills, technological innovation in the process of future employment or business, sets up the technological innovation consciousness, improve the production technology level of enterprises.

Developing education course system of "two-type and twolevel" entrepreneurship is the carrier of cultivating innovative and entrepreneurial talents. Education course of entrepreneurship should not only focus on cultivating students' entrepreneurial spirit and entrepreneurial quality, but also reflect the cultivation of students' professional technical skills and practical ability of innovation and entrepreneurship. In higher vocational colleges need to improve the existing system of entrepreneurship education courses, according to the students to start a business and the ability to post business demand, to form a creativity, creation and entrepreneurship ability as objective, to schedule time for the order, with industry enterprise production practice as the carrier, the joint venture set up two levels: the "double type" entrepreneurship education curriculum system, and gradually increase the intensity of entrepreneurship education, the formation of theory course and practice course of two types, the combination of two levels: post entrepreneurship and starting a business ability, the progressive development of entrepreneurship education curriculum system is shown in figure 2. Specifically, in terms of theoretical courses, in the first year of college, students' entrepreneurship and entrepreneurial knowledge education are emphasized, and general education courses are taken as the 
main courses to help students form a rational understanding of entrepreneurship. In addition to the special courses of education for entrepreneurship, education for entrepreneurship can be integrated with education for ideological and political education and professional basic courses. In the second year of my sophomore year, I designed the entrepreneurial education course, which was consistent with my major, to realize the integration of entrepreneurial education and professional education. In the third year, according to the needs of students, the establishment of the theory of practicability training and innovation department can be understood as the cultivation of two abilities. In the practical course system, higher vocational colleges and enterprises jointly serve as the main body of practical teaching. In the first stage, all students are taken as the objects, and students' innovative consciousness is cultivated through organizing students' field investigation of enterprises, inviting entrepreneurs and successful entrepreneurial alumni to exchange with each other, and carrying out entrepreneurial bb0 and other activities. Forming an intuitive understanding of innovation and entrepreneurship; the second stage is to create the production situation for students through on-campus training and corporate internship. Through the "work" oriented "study, and under the special guidance of enterprise technical personnel or teachers in higher vocational colleges. Take the application of technical skills as an opportunity to cultivate students' creative ability in the work process: in the third stage, students are allowed to participate in the development of new products and technological innovation of enterprises, take real projects of enterprises as the carrier, train students' ability to transform technology into capital in specific technological research and development of enterprises, and train their innovation and entrepreneurial ability.

Starting a business is a difficult process. Especially at the beginning of college students need more support. Although many higher vocational colleges have established institutions such as college students' entrepreneurship parks and business incubators for college students, the entrepreneurial support in practice is a relatively weak link in higher vocational colleges' entrepreneurship education. Problems encountered in research and development, initial operation management and market development of higher vocational colleges; On the other hand, compared with all kinds of loans and financing channels provided by the government to support college students to start their own businesses. Successful use of enterprise funds to complete the initial investment in entrepreneurial projects, more conducive to entrepreneurial success. As a for-profit organization, enterprises often fully evaluate the development prospect and potential value of entrepreneurial projects before participating in supporting entrepreneurial projects of students in higher vocational colleges, so as to ensure the return after capital investment. This puts forward higher requirements on the quality of technical innovation and entrepreneurship projects and the comprehensive quality of entrepreneurs. The purpose of establishing a technology-based incubation platform through school-enterprise cooperation is to accelerate the flow and transfer of technical achievements of students in higher vocational colleges to market products, to meet the needs of students in higher vocational colleges to start businesses directly based on technological achievements, and to be an important way for patent technology in higher vocational colleges to get off the shelf and onto the shelf. In the operation mechanism of technology-based enterprise incubation platform, technicians break the traditional "teacher + student" mode in organizational mode and advocate the formation of a new practical community of 'teacher + student + enterprise technical personnel". In terms of how technical tasks are created. Change the previous simulation and simulation projects, emphasize the introduction of enterprise real technology development projects; In the allocation of technical resources, appropriate introduction of the market mechanism. In the whole process, it is necessary for government departments to provide services such as policy guarantee, information dissemination and interest coordination, so as to effectively motivate students to give full play to their technological advantages, and enterprises to give full play to their technological achievements transformation, product r\&d and promotion as well as financial advantages. 4. It is an important guarantee to improve the teaching quality of higher vocational colleges to build the "dual teacher structure" teaching team of education teaching team, and it is enforced through national policies. As for the current situation of education teaching staff in higher vocational colleges, it is rare for teachers to master the basic knowledge and teaching rules of entrepreneurship, understand technological innovation, and turn technological innovation into productivity and meet the market demand. However, the healthy and sustainable development of education in higher vocational colleges is inseparable from an excellent teaching team of "double-tassel division structure". Therefore, it is necessary to supplement the shortage of education teachers in higher vocational colleges through school-enterprise cooperation.

\section{CONCLUSION}

Only by promoting the all-round development of students as the teaching objective, cultivating students' ability to start enterprises as the objective of education, and implementing school-enterprise cooperation as the educational strategy, can we truly achieve the goal of cultivating entrepreneurial talents.

\section{REFERENCES}

[1] Pinchot, G. Intrapreneuring: Why You Don7t Have to Leave the Corporation to Become an Entrepreneur[M].New York: Harper and Row,1986.28-48.

[2] Antoncic, B., Hisrich,R.D. Intrapreneurship: Construct Refinement and Cross--cultural Validation[J].Journal of Business Venturing,2001,16(5):495-527.

[3] Luchsinger, V., Ray Bagby, D. Entrepreneurship and Intrapreneurship: Behaviors, Comparisons, and Contrasts [U].SAM Advanced Management Journal, 1987, 52(3):10-13.

[4] Davis, K.S. Decision Criteria in the Evaluation of Potential Intrapreneurs[J]. Journal of Engineering \& Technology Management. 1999, 16(3-4):295-327.

[5] XU xiao-zhou, LI Zhi-yong. System and policy choice of education in Chinese universities[J].Education development studies.10,(11):12-18.

[6] YANG Xiao-fei. Research on education and innovative talent cultivation in Chinese universities[J].Research on higher education in China.2015(1).

[7] Background of "double innovation"[J].Journal of Nanning College for Vocational Technology.2017 (1). 